\title{
Difference in Diversity and Abundance of Echinoderms in the Neritic Zone at Sayang Heulang Beach and Cibako Beach, Garut
}

\author{
Sriwahjuningsih $^{1}$, Hudiana Hernawan ${ }^{2}$, Fitri Eka Silviani ${ }^{3}$, Leni Srimulyani ${ }^{4}$ \\ Program Studi Pendidikan Biologi, Institut Pendidikan Indonesia Garut \\ Jl. Pahlawan no 32 Sukagalih, Tarogong Kidul Garut 44151 \\ e-mail : ningsriwahjuning@gmail.com
}

\begin{abstract}
Difference in Diversity and Abundance of Echinoderms in the Neritic Zone at Sayang Heulang Beach and Cibako Beach, Garut. The development of tourism in the oceans and the coast of South Garut, can increase ecological pressure on ecosystems and marine resources to influence fauna diversity. One of fauna diversity in the ocean region that is vulnerable and very sensitive to changes in environmental conditions are from the phylum Echinoderms. Echinoderms can used as bio indicators in the ocean. The purpose of this study was to determine the differences in diversity and abundance of Echinoderms in the Neritic zone on Sayang Heulang beach and Cibako beach, Garut. Sampling at each location was carried out at the lowest tide by pulling 3 transect lines (100 meters each) vertically from the coastline towards the sea. Squares of squares $(1 \times 1$ meter $)$ are placed with a distance between squares of 10 meters. Based on observational data, Echinodermata species which were found on the Sayang Heulang beach were 4 species with 1366 total Echinoderms found. While in Cibako beach there are 9 species with 2773 total Echinoderms found. Based on the results of the calculation analysis, the diversity index ( $\left.\mathrm{H}^{\prime}\right)$ on Cibako beach is higher than the one on Sayang Heulang beach, the level of population uniformity at Sayang Heulang beach and Cibako beach is moderate. While the most abundant species on both beaches is Ophioscoma erinaceus.
\end{abstract}

Keywords : Diference, Diversity, Abundance, Echinoderms, Sayang Heulang Beach, Cibako Beach.

\section{Introduction}

Indonesia's ocean and coastal areas have the highest diversity in the world, which is present in the form of coral reef ecosystems, mangrove forests, estuaries, seagrass beds, beaches, open seas, and deep-sea [1].

As is known, the beauty of the coastal ecosystem makes many people interested in visiting it, so that many beaches are developed into tourism places. However, tourism development can have a positive and negative impact, one of the positive impacts seen in improving the economy of the community, while the negative impacts include air pollution, water pollution, waste pollution and ecosystem damage[1]. [2] which states that tourism development can increase 
ecological pressure on ecosystems and marine resources, this increase in pressure will certainly be able to threaten the existence and sustainability of the surrounding ecosystems. One of the diversity of fauna in the oceans that is susceptible to changes in environmental conditions is from the phylum Echinoderms. According to Dahuri [3] the number of Echinodermata species in Indonesia reaches around 1,412 species or about $10 \%$ of the total species in the world. Echinodermata species are spread throughout most of the Indonesian seas, but their diversity and abundance vary from place to place.

According[4] three things make Echinodermata interesting to learn, namely: 1) Echinodermata is very sensitive to changes in the environment of seawater ecosystems, this can be easily known the loss of species from a particular area that is directly related to seawater polluted. So that Echinodermata can be used to study marine pollution, because they are easily affected by pollution; 2) the ability of Echinoderms to regenerate parts of their body, which are based on cell system recovery; and 3) Echinodermata has an extraordinary ability to cause changes in the substrate of the seabed. Of the three characteristics, Echinoderms can be used as bioindicators in the ocean, because they are sensitive to changes in conditions in the waters.

The purpose of this study was to determine the differences in diversity and abundance of Echinoderms in the Neritik zone on the Sayang Heulang beach and Cibako beach, Garut Regency

\section{Research Methods}

The research method used in this research is descriptive comparative research. Sampling is done using exploration. Where the sampling technique used was purposive sampling. As for the research time in April 2017, and the research location is the Sayang Heulang beach in the west with the boundaries of the Panyurugan (Curug) and Observation areas, as well as the Cibako coast with the Cipangisikan river estuary and Cibako river estuary.

\section{Results And Discussion}

From the results of identification on both beaches, 9 species were found on the coast of Cibako and 4 species on the beach of Sayang Heulang. The diversity index on the coast of Sayang heulang in 0.30 while in the coast of Cibako is 0.56 . 
Table 1. Recapitulation of the Echinoderm Diversity Index at Sayang Heulangdan Beach in Cibako Beach

\begin{tabular}{llllll}
\hline beach & O & H & E & A & total \\
\hline SH & 0,15 & 0,15 & - & - & 0,30 \\
CB & 0,14 & 0,16 & 0,16 & 0,10 & 0,56 \\
\hline
\end{tabular}

Ket :

$\mathrm{O}=$ Ophiuroidea,

$\mathrm{H}=$ Holothuroidea,

$\mathrm{E}=$ Echinoidea,

$\mathrm{A}=$ Asteroidea

Whereas based on the calculations that have been made on the abundance of each type of Echinodermata at Sayang Heulang beach and Cibako beach, only three types of fauna can be compared with abundance, namely Ophiocoma erinaceus, Holothuria scabra, and Holothuria leucospilota. This happens because only the three types of Echinoderms are found on both beaches

Table 2. Recapitulation of Echinoderm abundance at Sayang Heulangdan beach in Cibako beach

\begin{tabular}{llll}
\hline Pantai & O & Hs & HI \\
\hline SH & 1361 & 1 & 3 \\
CB & 2737 & 4 & 9 \\
\hline
\end{tabular}

\footnotetext{
Ket : $\mathbf{O}=$ Ophiocoma erinaceus,

$\mathbf{H s}=$ Holothuria scabra,

$\mathbf{H I}=$ Holothuria leucospilota
}

Several factors cause this difference to occur, namely, differences in the area of tidal areas, nutrient content, and human activities. Cibako Beach has a tidal area that is $\pm 300 \mathrm{~m}$ wide to the edge, while the beach of Sayang Heulang has a relatively short tidal area. On the beach Sayang Heulang, tidal area ranges from 150 m (Station I) - 60 m (Station III) towards the edge. Tidal areas that are relatively short and near the rim allow large waves and wave movements. This difference in the area of tidal areas results in differences in Echinoderm fauna diversity. The difference in the area of tidal areas also affects the availability of nutrients which are food for fauna Echinoderms that eat detritus, this occurs because of the influence of wave fragments that erode nutrients found in ecosystems on the coast.

This is different from the conditions on Cibako beach, which have greater diversity than the Sayang Heulang beach, because Cibako beach has a wider tidal area compared to Sayang Heulang beach, so Cibako beach has more abundant nutrients compared to Sayang Heulang beach. Besides, Sayang Heulang beach and Cibako beach are two beaches that have different functions. Cibako Beach is part of the Sancang Marine Protected Area (CAL) which is protected and as a germplasm storage area, while the Sayang Heulang beach is a tourist beach. This difference in a role is one of the causes of differences in diversity between Sayang Heulang beach and Cibako beach. Sayang Heulang Beach, which is visited by many tourists, causes 
ecological pressure on the ecosystems there, such as [1], that tourism development can increase ecological pressure on marine ecosystems and resources, increasing pressure will certainly threaten the existence and sustainability the ecosystem around it. As one of the consequences of tourism development is a decrease in water quality which in turn will cause a decrease in diversity.

The abundance of Echinoderms between the beaches of Sayang heulang and the coast of Cibako cannot be compared as a whole, this is due to differences in the diversity of Echinodermata species between the two beaches so that many species are found on Cibako beach but not found on Sayang Heulang beach and vice versa.

Three species of Echinoderms that can be compared to the abundance index, namely Ophiocoma erinaceus, Holothuria scabra, and Holothuria leucospilota. Because these three species were found both on Sayang Heulang beach and on Cibako beach.

Ophiocoma erinaceus on Cibako beach is more abundant than on Sayang Heulang beach. On the coast of Cibako, 2737 individuals were found while on the beach of Sayang Heulang only 1361 individuals were found. This happens because of the tidal region. Cibako Beach is more supportive of area and substrate and is protected from large waves compared to Sayang Heulang beach. According[5], those wave movements can destroy and carry objects that are exposed, including the substrate and one of them is sand. Sand affected by the waves can clog the respiratory system of Ophiuroidea

Besides, the difference in abundance is also due to a large amount of human activity carried out in the intertidal region on the Sayang Heulang beach, these activities include the activities of fishing fishermen, swimmers, and even tourists who take snaking stars to play with. The activity resulted in the disruption of Ophiocoma erinaceus habitat so that its abundance was small. Because according to Stöhor et al., (2012) snaking stars are mobile biota where when they feel disturbed they will find a safer place. This is reinforced by the statement of Nugroho[6], according to him the abundance of snaking stars is reduced due to the ecological pressure from the outside, namely visitors or tourists who carry out recreational activities during low tide.

Holothuria leucospilota is one of the species included in the Holothuroidea class. This sea cucumber enters the family Holothuriidae with the genus Holothuria. The sample obtained has a long, cylindrical, soft and brownish body. The tube leg is black and long with a transparent colored sucker tip. The mouth is located in the anterior ventral part with the peltate-shaped tentacle (shield). Classification of these marine biotas, namely Kingdom Animalia, Phylum Echinodermata, Class Holothuroidea, Order Aspidochirotida, Family Holothuriidae, Genus Holothuria,

Furthermore, the presence of species from the Holothuroidea class (Holothuria scabra and Holothuria leucospilota) on the coast of Cibako was superior with the discovery of thirteen individuals compared to the Pantai Sayang Heulang which was only found in four individuals. Holothuroidea is a fauna type of detritus-eating Echinoderms, according to Yusron[7] Echinoderm fauna distribution is mainly influenced by food factors and how to eat from each type. Seeing the condition of the Cibako coastal waters which have extensive tidal areas with abundant detritus resulting from the decomposition of mangrove litter and other trees that cover the coast, allowing an abundance of Holothuroidea class species to be more abundant than on the Sayang Heulang coast which has a short tidal area and rare tree canopy cover 
Sayang Heulang Beach as one of the tourist beaches that are in great demand by tourists, results in high human activity, this will have an impact on decreasing fauna abundance, because according to Junianto [8] high human activity in utilizing aquatic areas can lead to a decrease in the quality of aquatic environment, which then affects the ecosystem, including the Echinodermata ecosystem

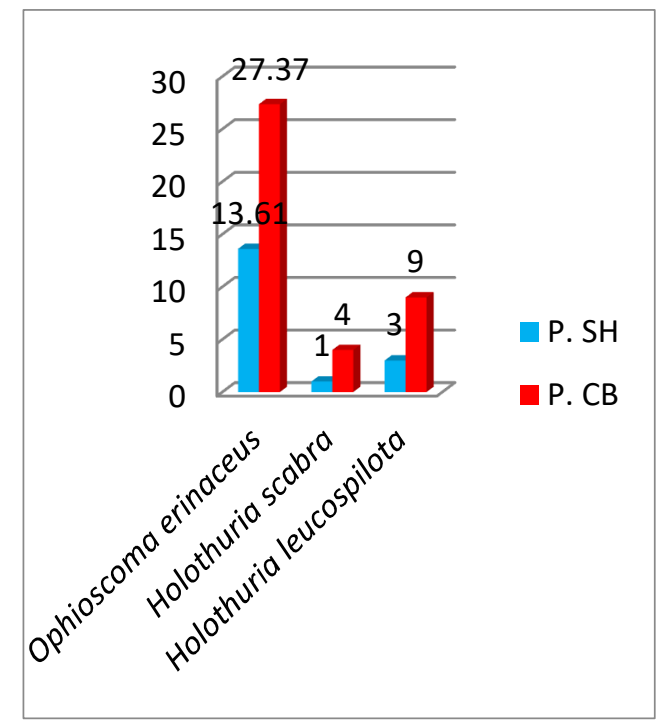

Figure 1. Number of Ophiocoma erinaceus x 100

P. SH : Pantai Sayang Heulang

P. CB : Pantai Cibako

A

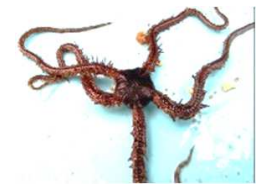

$\mathrm{C}$

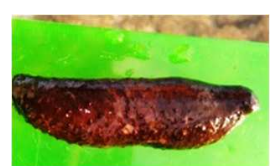

$\mathrm{E}$

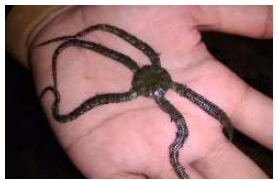

B

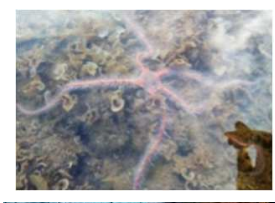

$\mathrm{D}$

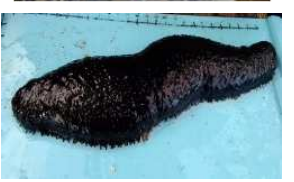

$\mathrm{F}$

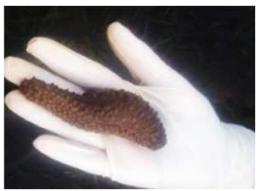




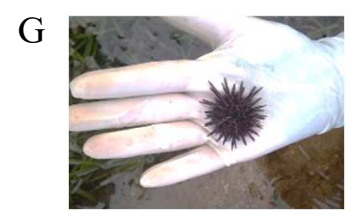

$\mathrm{H}$
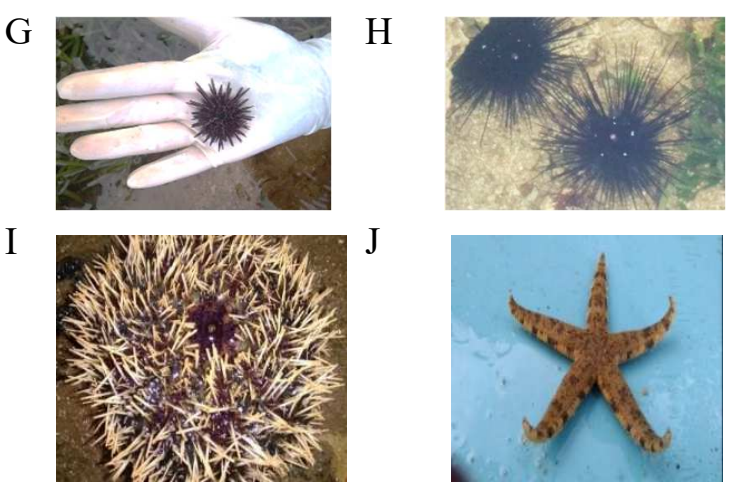

Figure 2. Echinoderms diversity at Sayang Heulang Beach and Cibako Beach

A. Ophiocoma erinaceus B. Ophiomastix annulosa C. Holothuria scabra D. Holothuria leucospilota E. Ophiarachna incrassate F. Holothuria impatiens G. Arbacia punculata H. Diadema setosum I. Tripneustes gratilla J. Archaster typicus

\subsection{Sayang Heulang Beach}

1) Black Star Spots (Ophiocoma erinaceus) Ophiocoma erinaceus has the characteristic discs of a pentagon-shaped body in brown- black, has five arms, the color of a light brown arm black, in the young Ophiocoma erinaceus arm there is a black ring line, but not found in adults, except for the Ophiocoma erinaceus arm who is experiencing regeneration. Ophiocoma erinaceus on the coast of Sayang Heulang is very abundant and is the most common type of Echinodermata, which is 1361 in the quadrant and found in 82 quadrants from a total of 90 quadrant observation samples. Ophiocoma erinaceus is found in all coastal substrates, namely sandy coral substrate, sandy seagrass, muddy seagrass, and coral.

2) Star Spread Red (Ophiomastix annulosa) Ophiomastix annulosa has the characteristics of a pentagon-shaped body, orange in color, on the body of the disc filled with thorns, the arm has two types of thorns, namely thorns with tapered ends and spines with rounded edges. The size of a thorn that has a rounded tip is larger than the size of a tapered thorn. Ophiomastix annulosa has a body size that is relatively larger compared to other snaking stars found, its arms- length is $\pm 23 \mathrm{~cm}$, lives on coral rock substrate overgrown by macroalgae, solitary life and is only found in one sampling area of Sayang Heulang Beach.

3) Sand Sea Cucumber (Holothuria scabra) Holothuria scabra or sand sea cucumber found on Sayang Heulang Beach has dark brown features with white spots on its body, relatively small size $\pm 8 \mathrm{~cm}$, on Sayang Heulang Beach Holothuria scabra found only one tail and lives behind rocks. The found Holothuria scabra is estimated to be immature, judging by its size and body texture 
4) Black Sea Cucumber (Holothuria leucospilota) Holothuria leucospilota which is found to have features of a long body with body parts shrinking towards the mouth. Also, there is an ambulacral foot on the surface of his body. Holothuria leucospilota was found in three quadrants, namely quadrants 49,52 , and 81 of a total of 90 sampling quadrants. The three Holothuria leucospilota species found life in basins that have sandy coral substrates and many overgrown with macroalgae and have a depth of more than $15 \mathrm{~cm}$.

\subsection{CIBAKO BEACH}

1) Black Star Spots (Ophiocoma erinaceus) On Cibako Beach Ophiocoma erinaceus is found to have the same characteristics as the features of Ophiocoma erinaceus on Sayang Heulang Beach, which has a body of pentagon-shaped discs, black and has black ring lines on the arms of the young Ophiocoma erinaceus or in the hands of regenerated Ophiocoma erinaceus. Ophiocoma erinaceus is found in all substrate found in Cibako Beach, namely sandy seagrass substrate, muddy seagrass, sand and coral rock. However, the larger size of Ophiocoma erinaceus is found in the coral substrate.

2) Green Spread Stars (Ophiarachna incrassata) Bintang Mengular Hijau (Ophiarachna incrassata) has characteristics, namely, a round disc body with moss green has five arms with dark green color interspersed with light green, thorns are only on the side of each arm, besides Ophiarachna incrassata is found solitary life. Ophiarachna incrassata is found at station three under the rock. In Cibako Beach, Ophiarachna incrassata is found, a type of snaking star that is rarely found, because of its solitary habits and habitat behind rocks. Ophiarachna incrassata is found at station three in quadrant 64 . When found, Ophiarachna incrassata sticks behind the rock when the state of low tide is low.

3) Sand Sea Cucumber (Holothuria scabra) Holothuria scabra or 'teripang pasir' found in Cibako Beach has a characteristic dorsal brown body older than the ventral part, has little white spot on the dorsal body, slightly flattened body, found on the beach with coarse sand, and live by hiding or immersing yourself under the sand.

4) Black Sea Cucumber (Holothuria leucospilota)

In Cibako Beach, the Black Sea Cucumber or Holothuria leucospilota which is found to have black body characteristics has ambulacral legs, Holothuria leucospilota has a body shape that tends to round and shrink towards the mouth. Holothuria leucospilota is found in muddy seagrass areas and hides under rocks.

5) Sea Cucumber Spines (Holothuria impatiens)

Sea cucumber spines or Holothuria impatiens have characteristics of a light brown body, there is a thickening of the skin that resembles thorns and is thicker and harder than other species in the Holothuroidea class. In the dorsal part of the body is bulging, (resembling the shape of a snail without a shell) but not towards the mouth, in the ventral section there are transverse lines. Holothuria impatiens are found in coastal areas with muddy seagrass substrates, this species hides under dead chunks of coral.

6) Pig Fur (short spines) (Arbacia punculata)

Short spiked pig feathers or Arbacia punculata have a rounded body shape, filled with short black spines, black body colors both ventral and dorsal. Arbacia punculata found on Cibako 
Beach in Jababitat under rocks or attached to Coelenterata's dead chunks. Arbacia punculata is the most common type of sea urchins found on Cibako Beach.

7) Sea urchins (long thorns) (Diadema setosum)

Diadema setosum is one of Echinoidae which is included in the Diadematidae family. This sea urchin has two sides, namely aboral and oral. In the aboral section, there is an orange anal ring and there is a blue or green color on the genital part, while in the oral part there is a mouth. The sample obtained has a black color throughout the body with long, tapered primary spines. $D$. setosum is a regular sea urchin because it has a rounded body horizontally. The classification of these marine biotas is Kingdom Animalia, Phylum Echinodermata, Class Echinoidea, Order Diadematoida, Family Diadematidae, Genus Diadema, Species Diadema setosum. Diadema setosum was found on the coarse sandy substrate and muddy seagrass.

8) Pig Bristle 3 (Tripneustes gratilla) On Cibako Beach found Tripneustes gratilla sea urchins which have characteristics namely round body, moss green body color alternating in purple, purple part of the mouth, having short spines and covering almost the entire surface of the body, thorn color from Tripneustes gratilla is white bone. Tripneustes gratilla is found at Station three at a depth of $67 \mathrm{~cm}$. Tripneustes gratilla is a type of sea urchin that is only found by one individual at Cibako Beach. Tripneustes gratilla species were found at station three in the 61 quadrants with muddy seagrass observation substrate.

9) Star of the Sea (Archaster typicus) Archaster typicus or sand starfish is the only species in the Asteroidea class that was found on Cibako Beach. The characteristics of the Archaster typicus found are that it has a star-shaped body because of its five arms, light brown body color with black shades on the dorsal, while the ventral part is yellow without a black hue. Besides, on the dorsal part of the thorns it is very short so that it only feels rough, but in the ventral part there is a longer thorn precisely on the side and in the middle part of the arm ventrally there is a shaky leg. This Archaster typicus species is found in the sand on the coast.

\section{Conclusion}

Based on the results of the research and observations that have been made, it can be concluded that the Sayang Heulang beach and Cibako beach have different diversity and abundance of Echinodermata species. This is caused by ecological factors, such as tidal area and nutrient content. Besides, human activity is also one of the causes. While the most abundant species on both beaches is Ophiocoma erinaceus 


\section{References}

[1] H. K. Baransano and J. C. Mangimbulude, "Eksploitasi dan Konservasi Sumberdaya Hayati Laut dan Pesisir di Indonesia," J. Biol. Papua, vol. 3, no. 1, pp. 39-45, 2011, doi:

10.31957/JBP.547.

[2] "DAMPAK PERKEMBANGAN PARIWISATA TERHADAP LINGKUNGAN TAMAN

NASIONAL KARIMUNJAWA," Ruang J. Perenc. Wil. dan Kota, 2013.

[3] R. Dahuri, Keanekaragaman hayati laut: aset pembangunan berkelanjutan Indonesia. 2003.

[4] M. I. Arnone, M. Byrne, and P. Martinez, "Echinodermata," in Evolutionary Developmental Biology of Invertebrates 6: Deuterostomia, 2015.

[5] Z. Mahmudi, "Pola Distribusi Populasi Kelas Ophiuroidea Di Zona Intertidal Pantai Bama Taman Nasional Baluran," 2015.

[6] W. Nugroho, Ruswahyuni, and Suryanti, "Kelimpahan Bintang Mengular (Ophiuroidea) di Perairan Pantai Sundak dan Pantai Kukup Kabupaten Gunungkidul, Yogyakarta," Diponegoro J. Maquares, vol. 3, no. 4, pp. 51-57, 2014.

[7] E. Yusron, "keanekaragaman Jenis Ekhinodermata di Perairan Likupang, Minahasa Utara, Sulawes Utara," Ilmu Kelaut. - Indones. J. Mar. Sci., vol. 15, no. 2, pp. 85-90, 2012, doi: 10.14710/ik.ijms.15.2.85-90.

[8] F. Y. Dwi Junianto, Henky Irawan, "ata kunci : Ekologi, Teripang, Desa Pengudang." 